NGTT Deel 54, Nommers 3 \& 4, September en Desember 2013

Leder, Arie C

University of the Free State

\title{
Divine Presence, then the covenants: An essay on narrative and theological precedence (Part two)
}

\section{ABSTRACT}

This essay examines the covenants with Noah, Abraham, at Sinai, and with David as they appear in their narrative sequence and contexts to show that they either secure the divine presence for the sake of humanity or God's people (Noah, Abraham [Gen. 15]), David), or secure the pledge of God's people to live in accordance with divine instruction in the divine presence (Abraham [Gen. 17], Sinai). The essay concludes that the theological theme of divine presence precedes that of the covenants.

\section{INTRODUCTION}

Part one of this essay argued that divine presence, not covenant, is basic to the divinehuman relationship (Leder 2012b), and that letting Scripture interpret Scripture according to the analogy of faith does not obviate an antecedent synchronic reading of the text on its own terms. 'This essay considers a defined set of covenants as they appear in their narrative sequence and focuses especially on their contribution to the narrative depiction of God's response to the problem of humanity's exile from divine presence, and on the narratively depicted response of Adam and Eve's and, subsequently, Abraham and Sarah's descendants.

\section{The approach to REAding the covenants in GeneSis-Kings}

This essay limits its discussion about the role and meaning of covenants to those depictions of covenant making events found in Genesis-Kings (GK), and then only to those of the suzerainvassal type ${ }^{2}$ : the covenants with Noah, Abraham, ${ }^{3}$ Israel at Sinai, and David. Furthermore, although GK's depiction of covenanting events employs elements recognizably belonging to the genre of ancient Near Eastern treaties or covenants, nowhere does the narrative present

1 "On its own terms" refers to the narrative as it develops its representation of the depicted events. Bolt (2007:180-181) charges Stek with biblicism, by which he means the reading of Scripture outside of the analogy of Scripture as used within a particular theological construction of federal theology. But, do we read Scripture to confirm an already developed system of theology (Prov. 27:17)? "Het hart van de gereformeerde dogmatiek is het Schriftbewijs; maar wil de dogmatiek niet aan het biblicisme ten slachtoffer vallen, dan zal ze er toch rekening mee moeten houden dat het altijd de geïnterpreteerde Schrift is, die zij als norma normans gebruikt. Tussen de dogmatiek en de bijbel zit altijd de interpretatie, wat maar niet een zaak van methodiek maar van hermeneutiek is" Wielenga (1996:467, emphasis added).

2 Parity treaties, such as marriage, do not shape Israel's self-understanding of the covenant relationship. Hosea's marriage metaphor depicts the suzerain-vassal relationship between the Lord and Israel. Human marriages are not suzerain-vassal type covenants, although some may function that way. As a covenant, marriage belongs to the category of parity treaties. Using the marriage metaphor to link the Noah covenant with Adam and Eve as depicted in Gen. 2:18-25 for purposes of arguing covenant continuity, as does Bartholomew (1995:19-21), is category confusion.

3 For simplicity's sake, the term "Abraham," and later "Sarah," is also used for all references to this character before Gen. 17. 
NGTT: Oopbron - http://ngtt.journals.ac.za

the audience with an ancient Near Eastern legal document as such. ${ }^{4}$ Rather, those elements are subordinated to the narrative depiction of the treaty-making event. ${ }^{5}$ Where oath swearing is part of the depictions of the covenants under review, such swearing is also crucial to the narrative occasion as heard by subsequent audiences. Oath ceremonies of one kind or another are clearly present in all the covenants within our scope, except that with David. ${ }^{6}$ Kalluteevill writes:

"Biblical texts inform us (sic) the normal situations when two parties enter into a covenant relationship: There are frictions or desires between persons or groups somehow apart (e.g., remote family, alienated family, citizens, etc, as well as strangers). There are often negotiations, a decision, a (mutual) sign of assent, and documentation ... . Covenant generally implies oath." (Kalluteevill 1982:5. Emphasis added).

The formalizing oath of post-lapsarian ${ }^{7}$ covenants not only legally secures the relationship God constituted between himself and humanity at creation, it also secures the constitutive relationship or a subsequent word in the development of that relationship when it is threatened in some way. That is to say, this essay responds to the question: Why does the GK narrative depict a covenant at this or that particular point in its description of the relationship between the deity and humanity?

Stek applies to the suzerain-vassal treaties in GK what Kalluveetill suggests is the case with parity covenants: they occur in the narrative's depiction of friction, a problem the covenant event addresses and presumably solves with a pledged promise, an oath. This is undeniably the case for the Noah and Abraham covenants, ${ }^{8}$ as Stek cogently argues (1994:35-36), and also the Sinai and David covenants, as we will see below.

In what follows I will argue that each of these covenants occurs in the narrative context of the divine presence, that in each case the covenant addresses a problem in the divinehuman relationship, and that the covenant depicted in this context secures the threatened relationship. I will consider these covenant-making depictions in their narrative sequence and

4 Deuteronomy comes close to having all the elements, but these are combined with Mosaic speeches (Miller 1990:10-16). Kline's view of the canon as a covenant type document, proceeds from the theological values of treaty elements. In addition, arguing that Genesis and the first part of Exodus "assume the character of an historical prologue" (Kline 1972:53) ignores the received shape of Genesis and Exodus and the manner in which these books uniquely contribute to the solution of the narrative problem: humanity's exile from the divine presence.

5 Thus, Ex. 19:4 functions like an historical prologue in that it evokes the Egypt and the desert experiences which set the narrative context for the Sinai covenant. For discussions of extant treaties, see McCarthy (1963); Kalluteevill (1982); Weinfeld (1970).

6 The word for covenant (ברית), absent from 2 Sam. 7, is used in 2 Sam. 23:5. The speech declaring this covenant displays similarities to a treaty, according to Kalluveetill (1982: 181).

7 In this essay the term "post-lapsarian" modifies textual referents, such as covenants, depicted as occurring after God's expulsion of Adam and Eve from the Garden.

8 Bartholomew's argument (1995:20-21) that the marriage covenant undermines Stek's position on covenant as an instrument for exceptional situations is itself problematic. Even though the marriage oath is not made in the context of an immediate threat, it anticipates potential threats that may invade the relationship in a world where a human word is often broken; in the post-lapsarian world people are by nature unreliable. Moreover, the marriage vow serves to legalize an already existing relationship, a legality which plays into a society's rules for breaking up a marriage in a way it determines to be just. In any case, it is not a matter of whether covenants do so simpliciter, but whether this is the case in GK's depiction of the Lord's covenanting. 
NGTT Deel 54, Nommers $3 \& 4$, September en Desember 2013

shape. That is, narrative organization rather than the collation of texts assumed to belong to a particular locus, the method of federal theology ${ }^{9}$ is the basis for my reading of the text.

\section{ReAding the COVENANTS FROM the POINT OF VIEW OF THE DIVINE PRESENCE}

The opening narrative interest of Genesis, cast in priestly terms as part of the dominant aspect of the metaphor of divine presence fundamental to the divine human relationship, depicts the creation as a sanctuary in which God constituted humanity as a priestly community totally dependent upon compliance to divine instruction for life to be considered "good" in that presence (Leder 2012b:182, 185). The instruction-compliance sequence in the Garden, which forbids eating from the Tree of Knowledge of Good and Evil, evokes this relationship and suggests that as God is holy, so are those who abide in his Garden presence. In that divinely created and provisioned place it is now up to Adam and Eve to work out the holiness, theirs by virtue of God's placing them in his near presence, by complying with divine instruction.

Historical critical studies do not consider Genesis 2:4 - 3:24 to be priestly material. Nevertheless, audiences familiar with Leviticus would hear formal and material echoes of its instructions. Frequent repetition of the verb "to eat" before and after disobedience (Gen. 2:16, 17; 3:1, 2, 3, 5, $6^{3}, 11^{2}, 12,13,14,17^{3}, 18,19,22$ ) evokes memory of the food laws central to clean living in the desert presence of the Lord. Failure to comply with food instructions in this presence would occasion a little death: eating forbidden food contaminates, leaving the offender unclean until evening (Lev. 11:25, 28,31). Uncleanness that follows upon other failures to comply leads to expulsion from the camp; reentry depends upon completing the cleansing rituals (Lev. 13:45$46 ; 14: 3-32$ ). These instructions require Israel to separate itself from "things that make them unclean, so they will not die in their uncleanness for defiling my dwelling place, which is among them" (Lev. 15:31). Certain kinds of uncleanness require death (Lev. 20:9-16).

Audiences familiar with Leviticus would hear echoes of these requirements in the instructioncompliance sequence of Genesis 2:17. They would recognize the priestly character of God's Garden instruction, that expulsion from fellowship with God is deadly, and that dying in an unclean state is the future of all who transgress the Garden prohibition: "The day you eat thereof you shall surely die." This intra-textual ${ }^{10}$ reading suggests that Adam and Eve failed to comply with a priestly regulation - not a covenant ${ }^{11}$ — constitutive of their being by virtue of their creation and location in the deity's intimate presence, and that uncleanness, not guilt, forced them to hide from God on his walking through the Garden (3:8).12 Expelled from the Garden, Adam and Eve die in their uncleanness, as will all their descendants (cf. מלפני in Jonah $1: 32,10)$, unless there is a cleansing that opens the way back into the divine presence. The subsequent GK narrative addresses the question: Since the way back into God's Garden presence is barred by the cherubim, what can overcome the deadly disruption between God and humanity?

9 On the post-Reformation topical method see Muller (2007:19, 21-22). The biblical theological method underlying this approach is discussed more fully in the third and final part of this essay (forthcoming).

10 Inter-textual and intra-textual repetition are forms of hidden textual meaning. Intra-textual allusions to the Primary History are crucial to understanding Esther. See Leder (2012a) and Grossman (2011:5-25).

11 The covenant of Sinai binds a community to God; the priestly instructions of Leviticus apply to the mode of cult and conduct in the camp (= Garden) indwelt by the deity, at the end of Exodus. Strictly speaking, the covenant making event ends in Ex. 24. The subsequent tabernacle instructions are not covenant stipulations, but temple or palace building instructions that provide for the indwelling of the deity.

12 On defilement and hiding, see Hutton (1994:151-160), Nelson (1993:17-38; 83-110), and Gorman (1997:5-7). 
NGTT: Oopbron - http://ngtt.journals.ac.za

As depicted in Genesis 3:1 - 11:26, post-lapsarian humanity has no satisfactory answer to the problems it is suffering. Good things are countered by bad (Gen 4:19-22; 4:23-24), death puts an end to every new beginning (Gen. 5:5, 8, 11, 14, 17, 20, 26, 31), and divinely placed curses permeate creation's divinely rooted fecundity (Gen. 1:28; 3:14, 17; 4:11; 5:29; 9:25). Nothing escapes the consequences of defilement. Human wickedness and violence beget universal death (Gen 6-8), the ultimate uncleanness (Lev. 11:32-40; 21:1-4, 10-12; cf. Mark 5:37-42; Lev. 22:4). All living things in the post-lapsarian world suffer divine judgement; only those who find themselves in the consecrated space designed by the Lord, and built in perfect, priestly, compliance by Noah, escape death. In this barren pre-diluvian world God promises a covenant with Noah and all living things. ${ }^{13}$

\subsection{The covenant with Noah: Divine rescue from divine destruction in God's presence (Gen. 6:18; 9:8-17)}

The first covenant GK depicts, promised in Genesis 6:18 and formalized in Genesis 9:8-17, is with Noah. Its occasion is God's determination to destroy (מחה, 6:7) humanity and all living things because humanity's wickedness and corruption has filled the earth with violence, ${ }^{14}$ in God's presence ( וירא יהוה, 6:8, 6:8), 12; God mitigates the decision to destroy all living things by promising to establish a covenant with an exceptionally righteous descendant of Adam, Noah. Before the covenant is ratified, God instructs Noah in the building of a rescue craft.

The verb "to establish" (קום)—_used of ratifying pre-existing 'words' (Deut 9:5), 'promises' (2 Sam. 7:25), 'threat' (Jer. 30:24), 'oaths' (Gen. 26:3), 'vows' (Num. 30:14), as well as 'covenants','15 _is sometimes taken to mean that the Noah covenant, as depicted in Genesis 9, is "a renewal of God's creation purposes as set out in Genesis 1. Noah is pictured as a second Adam,"16 whom God constituted in a creation covenant. However, affirming that refers to an antecedent "word," "promise," or "covenant," relationship, does not require that this antecedent reality be a covenant effectuated in the Garden.

How does Genesis 1:1 - 9:25 depict the antecedent reality that shapes the relationship between God and created humanity before God establishes a covenant with Noah? The emphasis in Genesis 1:1-2:3 is on creation as a sanctuary; Genesis 2:4-25 depicts earthly humanity receiving instructions to live in harmony with this divinely declared order. Conformity to such an order yields righteousness. ${ }^{17}$ Thus, Adam and Eve, constituted as divine image bearers,

13 Stek reasons that this and the other covenants are extra-ordinary, not exceptional (Bartholomew 1995), because royal figures do not ordinarily make covenants with peoples or nations, that covenant is not co-extensive with kingdom-kingship. That the narrative introduces a covenant of grant illustrates its extraordinary nature: Noah found grace (Gen. 6:8). Covenant, therefore, is not a necessary aspect of the divine human relationship, but a divinely introduced instrument of mitigation in the context of the Lord's declared intention to destroy all flesh (Gen. 6:5-8).

14 "Filling the earth" in Gen. 6:11, 13 conforms to the Lord's blessing of Gen. 1:28, except that the compliance is violent (חמס).

15 Wenham (1987:175), McEvenue (1971:74).

16 Bartholomew (1995:17-18) in a favorable review of Dumbrell's position (1984); Stek (1994:23, 23 note 42) disagrees with Dumbrell, pointing out that "most Reformed theologians have for good reasons shied

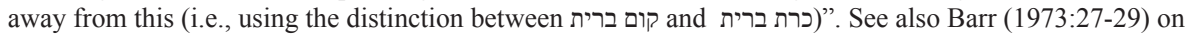
the idiomaticity of ברית and מבר ,נתן ,קום ,כרת paired with בוא ברית Both Neuhaus (2007) and Wielenga (1997), though they argue for Scriptural clarity, appear to accept uncritically the construct of an Adamic covenant.

17 "Geschichte wird verstanden als Vollzug von Schöpfung und Herstellung von Schöpfungsordnung" 
NGTT Deel 54, Nommers $3 \& 4$, September en Desember 2013

relate to God as priests to a deity, by creation (1:26), blessing (1:28), and instruction (2:15-17). Formally similar to instructions found elsewhere in the Pentateuch, the instruction in Genesis 2:16 in concert with the verb "to eat," evoke Israel's priestly tasks in God's desert presence. The verbs "to serve" and "to guard" commonly describe religious duties, particularly levitical duties (Wenham 1987:67). That these verbs also express human work in garden presence of God supports the reading that the relationship established between God and humanity is sacred and priestly, requiring the labor of keeping the Garden space clean. In the midst of humanity's defilement of the created order - "and God saw that (הנה) the earth was corrupt" (6:12) in contrast with "and God saw that (הנה) what he had made was very good" (1:31) Genesis 6:8 depicts Noah as exercising a priestly righteousness: "but in God's eyes Noah was righteous." Divine approval indicates Noah conformed to God's will with respect to the nature of the relationship antecedent to the covenant God promised Noah. This relationship is characterized by instruction-compliance, confirmed for the audience by the depiction of Noah's compliance with divine instruction (6:22).

This created relationship obtains in Noah's day as an irresistible moral order. Nevertheless, Adam and Eve's descendants now relate to God as defiled and defiling priests on the earthly plane of the heaven-and-earth sanctuary. The transgression of boundaries depicted in Genesis 6:1-4 is typical of a priestly theology of defilement (Nelson 1993:20-21; 36-38). Humanity's continuing and increasing defilement of God's presence is the narrative occasion for the flood, for the instruction for the vehicle of rescue, and for the covenant with Noah and all living things. Human defilement of God's presence continues after the flood and the covenant made with Noah and all living things, as indicated by the episode of Noah's nakedness (Wenham 1987:1999).

Repetition of the blessing of Genesis 1:28 in Genesis 9:1 and 7 indicates continuity of the priestly reality brought into being in God's presence. It is this antecedent reality and relationship which the covenant with Noah secures (cf. the verb (17) in two ways. First, God makes an oath never to judge the world with water again because he himself (cf. Heb. 6:13) had cleansed the world. In a world of capricious deities, whose wills are anything but clear, questions arise: Will God flood the earth again? How will we know? A royal grant type of covenant provides reassuring answers: The deity swears by himself using a terrible blood oath; a stronger vow cannot be found. The rainbow reminds Noah's descendants of God's pledge and power (Van Wolde 2011:385-389; 2013:124-149). Noah and all living things are assured that cosmic disorder will not come from God. By means of this covenant, then, God himself secures the continuity of the creation and of all living things in his presence.

Locating the establishment of the covenant with Noah after the repetition of the creation instruction links it to God's original creation purposes and indicates that the relationship constituted between God and humanity obtains. The clauses of the blessing in Genesis 9:17, however, are separated by descriptions of a new reality within the creation: animal fear of humanity and blood vengeance.

From this point on all living things, though still in a world suffering the consequences of humanity's defilement, are secure in God's covenanted presence because God has sworn by himself, a security not present in the pre-diluvian, post-lapsarian world. God's non-redemptive favor secures the old and now cleansed world against the recurrence of a divine dissolution of the creation into its elemental parts; it continues to enjoy the original blessing in the presence

Schmid (1974:16-18). 
NGTT: Oopbron - http://ngtt.journals.ac.za

of God. By covenant the creation's abundant fertility and humanity's cultural prowess are secured; and God has sworn not to be the author of disorder. But the water judgment only underscores humanity's wickedness for it persists in its desire to be like God (Gen. 11:1-9). Death also persists after the flood (Gen. 9:28; 11:28, 32) and even touches Israel's matriarch (Gen. 11:30); the flood has not cleansed the human heart (Gen. 6:5). The narrative turns to a greater than Noah to depict God's dealings with the threat that remains.

\subsection{The covenants with Abraham: secure blessing/growth in God's presence (Gen. 15;}

\section{7)}

The argument that Noah is a second Adam, and therefore represents continuity of a putative covenant with Adam (Bartholomew 1994:17), is true only in a limited sense. Like Adam, Noah is a righteous man who stands at the beginning of a new world, but now one with greater awareness of dangers; like Adam's, Noah's descendants fill the earth with wickedness (Gen. 8:21) and imperial violence (Gen. 10:8-12); and, like Adam, the defilement of God's presence in the garden continues with Noah and his descendants (Gen. 11:1-9). But Noah, whose postdiluvian world is not fundamentally different from Adam's pre-diluvian world, takes the world no closer to God than the post-lapsarian Adam could have: he and his descendants remain in a defiled and defiling world. Noah's world enjoys the fertility and cultural potential which Adam's did (Gen. 9:20; 10:1 - 11:26); it cannot escape the death sentence pronounced in Eden.

Noah is not a second Adam, however, because Adam is not alone in his role: the opening chapters of Genesis speak about humanity as male and female. Earthly response to divine instruction begins with a human pair, Adam and Eve, fecund by divine blessing and sufficiently instructed to manage the earth in God's presence. Their failure to comply brings death into the world, a death Noah could not overcome, and only temporarily survive by heeding divine instruction, for in the pre- and post-diluvian world of Adam and Eve and their descendants death regularly follows upon birth (Gen. 5:3-31; 9:29; 11:27-32). This conjoining of birth and death is uniquely embodied in Sarah, Abraham's wife. Unlike the first mother of all living, she is barren (Gen. 11:30) when she and Abraham abandon the defiled and defiling world of Noah in compliance with divine instruction (Gen. 12:1,4). Redemption of old world humanity does not begin with Noah but with an Abraham who has no vineyard to cultivate (cf. Luke 9:58; Rom. 4:13), and a Sarah whose barrenness, shameful in old world society, would be healed by God and turn her, and her daughters, into the mother of all truly living. The world shaped by Adam and Eve continues to enjoy life engendered by God's blessing, but it cannot escape death. In a sense, Sarah's barrenness is emblematic of that world: its fecundity inevitably ends in death. Contours of a future emerge at the beginning of the Abraham and Sarah narrative: instructions which promise blessings in a world suffering the curse, ${ }^{18}$ and a place to live unencumbered in the presence of God (Gen. 12:1-3). Abraham and Sarah are the second Adam and Eve.

The promise of land and a distinct form of divine self-disclosure are intertwined throughout the subsequent narrative, to be separated only at the end of GK when Israel and Judah are exiled from the divine presence in the land (Jerusalem). The land theme is enunciated in the divine speech: "Go (לך) to the land ..., , but not without linking it proleptically to divine selfdisclosure in the land "which I will show (ראה) you" (cf. "and the Lord appeared ... to the Lord who had appeared to him" [ראה, 12:7]), in connection with Abraham's building an altar after he arrives in the land. This divine self-disclosure at Bethel is the first of several such appearances

18 The root for blessing, ברך, is used five times in Gen. 12:1-3; the root for curse, ארר, is used five times in Gen. 3:15, 17; 4:11; 5:29; 9:25. 
NGTT Deel 54, Nommers 3 \& 4, September en Desember 2013

to the patriarchs ${ }^{19}$ at altars built to commemorate the Lord's elusive presence. ${ }^{20}$ Divine selfclosures frame the patriarchal narratives and the patriarchs' itinerancy in a land not yet theirs; they also set the context within which the audience hears about the covenants with Abraham.

The divine intention to create a new future through Abraham and Sarah remains unchallenged in Abraham's contact with nations $(12: 10-20 ; 14)$ and in the land that looks like the Garden of Eden (Gen. 13, esp. v. 10), until the narrative introduces an obstacle evocative of the fundamental narrative problem of the Pentateuch: death in exile from the Garden presence. Abraham and Sarah's old age evoke the divine curse that condemns all the descendants of Adam and Eve to death. ${ }^{21}$ Abraham defines the problem concretely: "O Lord God, what can you give me, I am 'walking according to your instructions childless"'? (15:2). The phrase, "walking according to your instructions" translates the present participle הלך, which in turn recalls the imperative לך (12:1) which itself introduces the volitional sequence of the primary instruction. Abraham's "continued walking" (הלך, present participle) in 15:2 is not a scattered wandering like that of the nations, but an intentional trek in continuity with Abraham's first response to the Lord instruction to go (לך): וילך (12:4)..22 Abraham's complaint is clear:"I am compliant. What is the state of the deity's expressed intention, now, at this time?"Because the audience knows Abraham and Sarah are old (Gen. 12:4; 16:16; 17:1), the reference to an heir evokes imminent death - the way of the old world - an obstacle Abraham cannot overcome. JPS translates the phrase, "seeing that I shall die childless."

By juxtaposing Abraham's demonstrated compliance to the deity's apparent failure to comply with the intentions expressed in 12:1-3 and 7, Genesis 15 defines the problem and then depicts the covenant which solves the problem. After Abraham trustingly responds to God's new

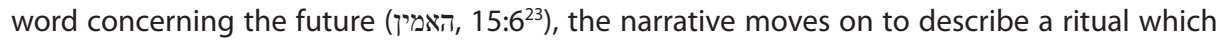
approximates the self-maledictory aspect of a suzerain vassal covenant, more specifically, of a royal grant. By it God swears that Abraham's descendants (זרו, 15:5, 13, 18) will inherit the land, thereby securing Abraham's promised future in his presence. That this is a promised future in God's presence becomes clear as the narrative develops a second obstacle.

Where Genesis 15 defines the narrative problem in terms of Abraham's compliance and old age, Genesis 16 addresses the problem of Sarah's barrenness. Unlike her husband, Sarah does not complain to God. Rather, she employs the available cultural resources, a surrogate, to overcome the obstacle, and involves Abraham in "solving" the problem, thereby evoking Eve's offering Adam the fruit from the forbidden tree. ${ }^{24}$ The complications of Sarah's actions

19 Abraham: ראה, Gen. 15:17; 22:14 (Ni); Abraham subject 22:4, 8, 13 (focusing on progeny, זרע), builds an altar, 22:8; Jacob at Bethel: ראה, Gen. 35:1, 7 (and זרע) 46:2; Jacob subject, 28:12 (זרע (זרע).

20 Terrien (1978). These appearances converge at Sinai with the indwelling of the presence in the tabernacle and subsequently in Zion and Solomon's temple. Newing $(1985: 7,10)$ argues that Ex. 33, which focuses on the divine presence, is at the center of a chiasm of the Pentateuch and 1 Kings 6-8 as the center of a chiasm of Joshua-Kings.

21 The regular notations about Abraham's age reminds the reader of this fundamental problem facing Abraham's way with God.

22 The verb הלך describes God (3:8), Enoch (5:24), Noah (6:9), and appears again in 17:1.

23 See Kline (1968).

24 Berg (1982:10), cited by Wenham (1994:8), writes: "The actors correspond: in Gen. 16:3 the woman takes the initiative as she does in 3:6b. The recipient in both texts is the man, in Gen. 16:3 the husband, in Gen. 3:6b the man for whom the woman was created as a partner. In both stories the man reacts appropriately to the woman's action. In 3:6b he eats the proffered fruit; in 16:4a he goes in to the offered Hagar. The means (of sin), the fruit/Hagar, is accepted by the man. The sequence of events is similar 
NGTT: Oopbron - http://ngtt.journals.ac.za

include Hagar's refusal to see Ishmael as Sarah's child, ${ }^{25}$ but Abraham sides with Sarah against the Egyptian. Egypt and what she represents, is not part of Genesis' solution to humanity's problem. $^{26}$

Sarah's attempt to overcome her barrenness (=death) forms the narrative occasion for God's securing the promise by means of another covenant. In his appearance (ראה) to Abraham God instructs him to "walk in my presence and be blameless" (התהלך לפני והיה תמים, Gen. 17:1; cf. תמהן (רמים

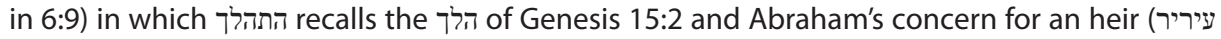
וואנכי הלך, הלך This evocation of Genesis 15, as expressed by heard in the context of Sarah's attempt to procure an heir, is followed by two simple waw + cohortative constructions that follow on the imperative וארבה + ואתנה :והיה תמים and the imperative. This reads: "Walk before me and be blameless, [then it is my intention that] I will make my covenant between me and you, and (that) I will make you very great in number."27 The verb of appearance (ראה) in this text recalls Abraham's unique way in God's presence (cf. Gen. 12:7) and reinforces the instruction to "walk in my presence."The covenant offer makes clear that, by binding himself to God as a vassal to a suzerain, Abraham and his descendants are committed by self-maledictory oath to God's way and time of fulfilling the promise of an heir.

Genesis 15 and 17 address the concern for Abraham and Sarah's promised heir with a view to instructing their audience that they - Abraham and Sarah's descendants - are bound to God's ways as vassals and that God has bound himself to them as a beneficent suzerain. These covenants not only secure the instructions of Genesis 12:1-3 in God's presence, but also the fulfillment of its promised future.

\subsection{The Covenant at Sinai (Ex. 19-24)}

Israel's promised future is realized in part in Joseph's wise administration of Egypt's fertility such that all the nations of the earth (cf. Gen. 12:3) come to Egypt to escape death by famine. In this way Joseph's righteous handling of affairs recalls humanity's rescue in righteous Noah's ark. In both cases, however, the rescue is temporary: death continues to ravage post-diluvian humanity and in Egypt a new Pharaoh, ignoring Joseph's rescue from death by universal famine

in both cases: the woman takes something and gives it to her husband, who accepts it. This leads to the conclusion. By employing quite similar formulations and an identical sequence of events for Gen. 3:6b and 16:3-4a, the author makes it clear that for him both narratives describe comparable events, that they are both accounts of a fall." This reading supports the pairing of Adam/Eve and Abraham/Sarah as first parents, of the human race and the holy race (זרע הקודש), Ezra 9:2) respectively. Theologically, this means that Abraham's spiritual descendants fell "in Abraham" as they did "in Adam," and that the temptation that led to that fall is not the desire to be like God, but to be like the nations in their way of solving humanity's problem: the cultural resources and practices. Hagar's Egyptian identity evokes the role of Egypt in Genesis and Exodus: both a help and a hindrance to God's way with Abraham among the nations. This also supports the parallel between Adam-Eve and Abraham-Sarah.

25 "Hagar conceived, but she did not think of disowning the blessing of her womb in favor of Sarah." Von $\operatorname{Rad}(1970: 191)$.

26 Abraham's ambivalent actions with respect to Pharaoh (Gen. 12:10-20) and Hagar (16:1-6), anticipates that of his descendants in the desert (Ex. 16:3; Num. 14:2; 21:5). The narrative depiction of Abraham's siding with Sarah against Hagar the Egyptian confronts the reader with the proper attitude to Egypt, i.e., the nations: it may be helpful, as it was in the time of Joseph, but it has no "share or claim or stake in [the building of] Jerusalem" (Neh. 2:20 JPS [Horonite, Ammonite, Arab]; cf. Ezra 4:3 [the enemies of Judah and Israel]). Ezra 9:1 expands the traditional list of seven nations to include Egypt and other nations.

27 The cohortative after the two imperatives expresses intended result. W\&O 33.6 (\#3) 
NGTT Deel 54, Nommers $3 \& 4$, September en Desember 2013

and threatened by Israel's enormous fecundity, develops measures to strangle Israel's future. Enormous growth in Egypt signals the fulfillment of God's word to Abraham (Gen. 15) and, by using the vocabulary of the blessing (Ex. 1:7; cf. 1:28), the fulfillment of that foundational word among the descendants of Abraham and Sarah. God's blessing of Israel in Egypt becomes the occasion of a threat to Israel's existence, for if universal death by famine has been avoided under divine guidance, a new Pharaoh is unwilling to acknowledge God's care of all nations(Ex. 1:8); he fears Israel's fertility (Ex. 1:8-9) and attempts to counter Israel's blessed future.

Egypt threatens Israel's future in two ways. First, Pharaoh impresses God's altar builders, God's vassals by Abrahamic covenants, to serve the Egyptian ship of state by forcing them to build the store cities of Pithom and Rameses. When this enforced vassalage only increases Israel's fertility, a second policy requires that all male Israelite new-born be drowned in the Nile. Thus Israel's future human progenitors could not engender the promised seed; the Israelite women would be absorbed into Egyptian society to bear fruit from alien seed. This policy is intensified when the midwives rescue the new-born males, and Pharaoh commands his own people to commit full-blown genocide. Israel's seed would be devoured by the nations (בלע, Jer. 51:34; Lam. 2:5, 16; Ezek. 36:3; Hos. 8:8;). But one of those threatened Israelite children survived this watery death in an ark, Moses (2:3, 5 [תבה]; Gen. 6:-8:19). He would rescue Israel from death in Egypt for God remembered his covenants with Abraham, Isaac, and Jacob (Ex. 2:23-25). The swallower would be swallowed (Ex. 7:12; 15:12; Jer. 30:16), and Moses would lead Israel to Sinai where they would serve the Lord (Ex. 3:12, עבד ) and not Pharaoh, and receive instructions to build their Redeemer's earthly throne-room.

The rescue begins with an 80 year old Moses finding himself in God's fiery presence (ראה, 7x in

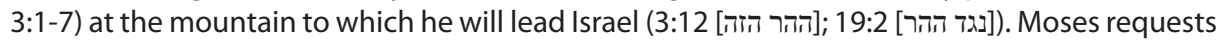
that Israel be allowed "to serve" (עבד: 7:16; 8:1 [7:20 MT]; 8:20 [8:16 MT]; 9:1, 13; 10:3, 17, 27) in the desert, that is, to demonstrate their vassal fealty to their covenant God. Only after ten mighty works does Pharaoh say: עבדו, לכו (Ex. 12:31; cf. 10:24). Thus, where before Israel was depicted as Pharaoh's enforced vassals (Ex. 1:13-14, 5x; 2:23 twice), or as acknowledging their vassal status (three times עבדיך by the Hebrew foremen, Ex. 5:15, 16), the plagues - the response of the God of the covenants with Abraham (2:24-25; 3:6-10; 6:6-8) - points to Israel's true covenant Overlord. And, as the waters judged the world for its corruption in the days of Noah, so the Sea swallowed Pharaoh/Egypt for its arrogant attempt to subvert the future God secured for Israel through his covenants with Abraham. Under his watchful presence (13:21$22 ; 14: 19-20,24)$ Israel was led through the Sea on dry ground, into the desert.

But oppression took its toll. When still in Egypt, Israel had refused Moses' leadership because of Egypt's cruel bondage ( עבדה קשה, 6:9). Now, during the escape fear of Pharaoh's pursuit disclosed a preference for Egyptian bondage over what the desert might offer (Ex. 14:1112). In the desert they pined for Egypt's sustenance, suggesting death in Egypt would have been better (Ex. 16:3). This is not a covenant people emulating Abraham's trust (האמין, Gen. 15:6; and see its appearances in Ex. 4:1, 5, 8, 9; 14:31; 19:9) in God. The impact of and rescue from Egyptian bondage and the challenge to be faithful to their rescuer in the desert, is the background against which the Sinai covenant is depicted.

As a covenant people Abraham's descendants lived in relative safety among the nations in

28 The translation "to worship" as often in NIV, fails to communicate the notion of the vassal status, that the עבד עat of "worship" is a matter of affirming that vassal status. Of the approximately 97 occurrences of the

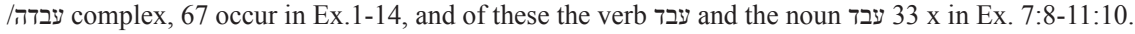


NGTT: Oopbron - http://ngtt.journals.ac.za

Canaan. The nations' attempts at harming this covenant family were few and rebuffed by the Lord (Gen. 12:10; 20; 26:7-11); the major obstacles arose from within the family: Sarah and Rebekah's barrenness, Jacob's deceit and its consequences, the affair of Dinah and Shechem. Such internal dangers will persist until the exile. The covenant people that the Lord rescued from Egyptian bondage, however, is unlike anything its ancestors in Genesis experience: it is Sarah disappearing into Pharaoh's or Abimelech's harem writ large. And, as the language of Israel's foremen and Israel's "commitment" to Egypt and Israel's desert move to Sinai demonstrate, Israel's covenant loyalty is anything but clear. The Sinai covenant secures Israel's loyalty as the Lord's, not Pharaoh's, vassal people. While in one sense it affirms the covenants with the patriarchs, the Sinai covenant is unique in that it administers relationship between God and his people, not only in terms of the promise of Genesis 12:1-3 as do the Abrahamic covenants, but also and especially in response to the threat of the nations to annihilate the promised seed. For that reason the Sinai instruction includes an extensive prohibition against serving the "other gods" of the nations (עבד, Ex. 23:20-33).

The Sinai event also depicts the beginning of the solution to the narrative problem defined in Genesis 2-3: exile from the presence of God for failure to comply with instructions. Having heard God's offer of covenant (19:5) in the context of God's mighty acts in Egypt and the desert (19:4), Israel swears a blood oath to obey and do everything the Lord commands (24:3, 7; 19:8), but only after experiencing God's dangerous presence (Ex. 19:16-19; 20:18-19; 24:17), a danger greater than the threat of Pharaoh. The remainder of Exodus depicts the instructions for and building of the tabernacle, interrupted by Israel's disloyalty with the golden calf, after which God indwells the tabernacle (Ex. 40:34-38). Only then does Israel find itself in the close presence of God, much like Adam and Eve in the Garden. The tabernacle section of Exodus addresses the narrative problem enunciated in Genesis, exile from the divine presence, not the covenant section.

The rest of GK depicts Israel's compliance or non-compliance in God's tabernacle and temple presence, measured not only by the blood-sworn covenant stipulations, but also by the subsequent tabernacle and levitical instructions (2 Sam. 6:6-7; cf. Ex. 25:26-27; Num. 1:50-51; Lev. 10:1-3), all of which are given from Sinai and later the tent of meeting in Israel's midst (Lev. $1: 1 ; 7: 38-39)$. Renewals of the Sinai covenant occur time and again to remind Israel of its loyalty (Josh. 8 and 24; 1 Sam. 12; cf. Neh. 9). Both people (Judges) and their leadership (Kings) fail. Good Josiah's repentant compliance with Mosaic instruction is not enough to cover Ahab's and Manasseh's idolatries (1 Kings 16:29-33; 2 Kings 21:1-16, esp. 13) and the defilement of the temple with the result that God removes Israel (2 Kings 17:18, 23) and Judah from his presence (2 Kings 23:26; 24:3, 20), as he did with Adam and Eve (Gen. 3:23). Defilement of God's presence is Israel's apostasy. But the narrative does not end on this sorry note. Rather, it reminds its audience that its exiled king was raised to sit at the conqueror's table (2 Kings 25:27-30). And Jehoiachin was a son of David (2 Sam. 7:12,16).

\subsection{The covenant with David (2 Sam. 7)}

The Davidic covenant belongs to the Lord's administration of the Sinai covenant in the Promised Land, specifically in the development of Israel's leadership through kingship as it focuses on David's house, in order to secure his people's life in his presence. The covenant pledge is partially realized when David's son Solomon builds the temple and the Lord indwells the temple after the priests bring the ark of the covenant into the Holy of Holies. On that occasion Solomon declares that God has brought his people into the rest and fullness of the 
NGTT Deel 54, Nommers $3 \& 4$, September en Desember 2013

promises given through Moses (1 Kings 8:56). The subsequent history of the Davidic kings and the temple ends in the latter's utter destruction. Nevertheless, the temple ruins reinforce the narrative (cf. Josh. 6:27; 1 Kings 16:34):
"als Ruine ist das Jerusalemer Heiligtum aber nicht obsolet geworden, es erwies sich vielmehr als "das integrierende Element, das es den exilierten, den nach Ägypten geflüchteten und den im Lande verbliebenen Judäern ermöglicht, ihre religiöse Identität zu bewahren." Auf diese Tempelruine richteten sich die Gebete des Volkes, aber auch die theologischen Reflexionen eines Ezechiel oder der Deuteronomisten aus."29

But how can God dwell in the ruins? What of God's presence with his people (Ezek. 1)? The covenant with David, only hinted at with the survival of Jehoiachin (Von Rad 1966a), reminds the exiles of the Lord's oath to provide a trustworthy king to lead his people, among whom he would come to rest. Hope and life in the divine presence coincide in God's covenant with David because with that covenant God binds himself to secure a trustworthy Davidic leadership for his people, and, through this pledged leadership, secures the divine presence in the midst of his people, a presence depicted by the ark of the covenant.

\subsubsection{The ark, divine presence in the land: from triumphant entrance to humiliating exile}

The ark begins its journey to Jerusalem at the foot of Sinai as the throne of God in the midst of Israel (Num. 10:33-36), a people fully instructed by and committed to the Lord's victory march to the Promised Land by self-maledictory oath (Ex. 24:3-8). It will come to rest after the Lord has defeated all his people's enemies through David (2 Sam. 8; cf. Josh 21:44; 2 Sam. 7:11), at the temple of Jerusalem. ${ }^{30}$ David's role in bringing the ark to Jerusalem from its exile (2 Sam. 6; cf. 1 Sam. 7:2) sets the stage for the covenant in 2 Samuel $7 .{ }^{31}$

The ark's journey begins with the fear it evokes among the nations (Josh. 2:8-11; 5:1; cf. Ex. 15:14-16; 1 Sam. 4:6-9), continues with a triumphant crossing of the Jordan and total destruction of Jericho by the Lord of all the earth (Josh 3:11, 13; 6:6-21). Divine instruction from the place where the Lord dwells, the ark, directs the campaign to complete the conquest and manage the distribution of the inheritance (Josh. 7:6, 23; 8:33; 18:1, 8, 10; 19:51; Jud. 20:2728). Failure to do so (Josh. 9:14; cf. 22:19) hampers the campaign. After a time of almost ceasing to be, the word of the Lord came to Israel again through Samuel, who slept "where the ark of the Lord was" (1 Sam. 3:3; 3:21), but the ark is taken into exile by the Philistines (1 Sam. $4: 11$, Ni) when Israel takes it into battle without divine permission. Although the Philistines bring it back to the land, the ark remains at the edges of Israel's existence (1 Sam. 7:2); Samuel, and subsequently other prophets, is the only connection between God and Israel. The ark remains in limbo until David brings it to Jerusalem. Juxtaposed to this event is David's desire to build a house for the ark, and God's pledge to build David a royal house instead (2 Sam. 7). God's covenant with David secures the kingship and through it the place where the ark of the Lord of all the earth will have its resting place; until the destruction of the temple when all its appurtenances go into exile (2 Kings 25:13-15; cf. Ezra 1:7; Dan. 1:2), and the ark of the covenant is no more.

29 Janowski (1987:190-191), citing Otto Weippert.

30 Like Noah's ark (תבה) at the end of its journey, the ark of the covenant (נרון) rests at the end of its journey (Gen. 8:4 [נוחה]); 1 Kings 8:6-8, 56 [נוח]]; cf. Num. 10:33, 36 [נוח]). On the ark, see von Rad (1966b).

31 God's pledged promise in 2 Sam. 7 is called a covenant in 2 Sam. 23:5 and Pss. 89:3 and 132:11-12. 
NGTT: Oopbron - http://ngtt.journals.ac.za

\subsubsection{The covenant with David and the presence of God}

The entry of the ark into Jerusalem, escorted by the Lord's warrior chief, as the end of the Lord's long victory march begun on Passover night, illuminates David's desire to build a house for the ark. The construction of the tabernacle in Exodus properly memorialized the Lord's victory over Egypt (Ex. 29:43-46; 2 Sam. 7:6), why not build a memorial at what appears to be the end of the journey that began Passover night?

Having defeated the Philistines decisively (2 Sam. 5:17-25) and having received rest from his enemies all around (2 Sam. 7:1) it is only proper for David to attribute this victory to the Great King who had given David these victories (2 Sam. 5:19, 23, 25; 8:14b). ${ }^{32}$ Furthermore, the Lord had already blessed the houses of Obed-Edom, Israel, and David (בית). The next logical step is to build a palace (בית) to house the divine presence (לפני יהוה in 6:5, 14, 16, 17, 212 and לפני ארון in 6:4). The prophet Nathan agrees; the Lord does not (2 Sam. 7:3, 4-17). Instead, by royal grant covenant for David's righteous deeds (2 Sam. 8:15) the Lord pledges to secure David's house (בית), a house involved in building and maintaining God's house: Solomon and Josiah; a house that survives the destruction of Jerusalem and the temple (2 Kings 25:27-30, Jehoiachin); a house that would be involved in the building of the second temple (Haggai 2, Zerubbabel, grandson of Jehoiachin), when the ark was no more. Although built by a scion of David's house, that temple would not be the seat of God's indwelling. It would be the task of the seed of Abraham and David to secure the divine presence in a house (תיב) built with living stones (vaoc, John 1:14; 2:19-21; Matt. 1:12-16, 23; 2 Cor. 6:16-18; 1 Peter 2:4-10).

\section{CONCLUSION}

This essay has examined the covenants with Noah, Abraham, at Sinai, and with David to show that, as they appear in their narrative sequence and contexts, they either secure the divine presence for the sake of humanity or God's people (Noah, Abraham [Gen. 15]), David), or secure the pledge of God's people to live in accordance with divine instruction in the divine presence (Abraham [Gen. 17], Sinai). This supports the argument that the theological theme of divine presence precedes that of the covenants. The third and final part of this essay will reflect will reflect on the narrative and consequent theological precedence of the theme of divine presence over that of covenant.

\section{BIBLIOGRAPHY}

Barr, J. 1973. Some Semantic Notes on the Covenant, in Beiträge zur alttestamentlichen Theologie. Fs. W.

Zimmerli. Göttingen: Vandenhoeck \& Ruprecht.

Bartholomew, C.G. 1995. Covenant and Creation: Covenant Overload or Covenantal Deconstruction, CTJ 30:11-33.

Berg, W. 1982. Der Sündenfall Abrahams und Saras nach Gen 16:1-6, BN 19:7-14.

Bolt, J, 2007. Why the Covenant of Works is a Necessary Doctrine. Revisiting Objections to a Venerable

Reformed Doctrine, in Johnston G.L.W. \& Prentiss Waters, G. By Faith Alone. Answering the Challenges to the Doctrine of Justification. Wheaton, IL: Crossway.

Dumbrell, W. J. 1984. Covenant and Creation: A Theology of Old Testament Covenants. Grand Rapids: Baker. Gorman Jr., F.H. 1997. Leviticus. Divine Presence and Community. ITC. Grand Rapids: Eerdmans.

Grossman, J. 2011. Esther. The Outer Narrative and the Hidden Reading. Shiphrut 6. LTHS.

Winona Lake: Eisenbrauns.

Hutton, R.R. 1994. Charisma and Authority in Israelite Society. Minneapolis: Fortress.

32 See Leder (2010:43-53) on memorializing military victories in ANE. 
NGTT Deel 54, Nommers $3 \& 4$, September en Desember 2013

Janowski, B. 1987. Ich will in eurer Mitte Wohnen, JBT 2:163-193.

Kalluteevill, P. 1982. Declaration and Covenant. Rome: Biblical Institute.

Kline, M.G. 1968. Abraham's Amen, WTJ 31:1-11.

Kline, M.G. 1972. The Structure of Biblical Authority. Grand Rapids: Eerdmans.

Leder, A.C. 2010. Waiting for the Land. The Story Line of the Pentateuch. Phillipsburg: P\&R.

Leder, A.C. 2012a. Reading Esther after Joshua. Rest in the Exile and the Diaspora, in Noort, E. The Book of Joshua and the Land of Israel. Peeters: 267-279.

Leder, A.C. 2012b. Presence, then the covenants. An essay on narrative and theological precedence. Part One, NGTT 53.1-2:179-193.

McCarthy, D.J. 1963. Treaty and Covenant. Rome: Biblical Institute.

McEvenue, S.E. 1971. The Narrative Style of the Priestly Writer. AB 50. Rome: Biblical Institute.

Miller, P.D. 1990. Deuteronomy. Interpretation. Louisville: John Knox.

Muller, R.A. 2007 Toward the Pactum Salutis: Locating the Origins of a Concept, MJT 18:11-65.

Nelson, R.D. 1993. Raising Up a Faithful Priest. Community and Priesthood in Biblical Theology. Louisville: Westminster John Knox.

Neuhaus, J.J. 2007. An Argument against Theologically Constructed Covenants, JETS 50:259-273.

Newing, E.J. 1985. The Rhetoric of Hope: The Theological Structure of Genesis-2Kings, Colloquium 17.2:115.

Rad, Von G. 1966a. The Deuteronomic Theology of History and I and II Kings, in The Problem of the Hexateuch and Other Essays. London: 205-221.

Rad, Von G. 1966b. The Tent and the Ark, in The Problem of the Hexateuch and Other Essays. London: 103124.

Schmid, H.H. 1974. Schöpfung, Gerechtigkeit, und Heil. 'Schöpfungstheologie' als Gesamthorizont biblischer Theologie, in Altorientalische Welt in der altestamentlichen Theologie, 6th ed. Zürich: Theologischer Verlag.

Stek, J.H. 1994. 'Covenant' Overload in Reformed Theology, CTJ 29:12-41.

Terrien, S. 1978. The Elusive Presence. San Francisco: Harper \& Row.

Weinfeld, M. 1970. The Covenant of Grant in the Old Testament and in the Ancient Near East, JAOS 90:184-203.

Wenham, G.J. 1987. Genesis 1-15. WBC. Waco: Word.

Wenham, G.J. 1994. Genesis 16-50. WBC. Waco: Word.

Wielenga, B. 1996. Over het vredesverbond als noachitisch verbond. Pactum salutis in Vetere Testamento, Skriflig 30:457-469.

Wolde,Van E. 2011. The Bow in the Clouds in Genesis 9:12-17: When Cognitive Linguistics Meets Visual Criticism, in Clines D.J.A. Van Wolde, E., A Critical Engagement. Essays on the Hebrew Bible in Honour of J. Cheryl Exum. Sheffield.

Wolde, Van E. 2013. One Bow or Another? A Study of the Bow in Genesis 9:8-17, VT 63:124-149.

\section{KEY WORDS}

Covenant

Oath

Pledge

Presence

Secure

\section{TREFWOORDE}

Verbond

Eed

Belofte

Teenwoordigheid

Veilig

Arie C. Leder

Research Associate, Faculty of Theology, University of the Free State, Bloemfontein. 
NGTT: Oopbron - http://ngtt.journals.ac.za

Professor of Old Testament, Calvin Theological Seminary

3233 Burton SE, Grand Rapids, Michigan, USA

E-mail: lede@calvinseminary.edu

1-616-957-7023 